\title{
Meat trade: need for international standardization?
}

\author{
María Eugenia D’Amato, Sean Davison and Daniel Corach
}

\begin{abstract}
Extensive substitution and undeclared species have been recently detected in meat products in South Africa, Europe and Asia. Here we review the methodologies utilized in the identification of species in red meat products and highlight the advantages and drawbacks of these methods. The problem is of a different nature in countries with easily accessible game meat and poor or nonexistent monitoring systems in place. Recommendations are drawn for meat DNA testing in these two scenarios.
\end{abstract}

\section{Introduction}

Extensive substitution of meat products has been detected in the South African market. The finding of approximately 70\% substitution for red meat products of domestic or wild animals $[1,2]$ gained sensational publicity, similarly to the finding of beef substituted by horse meat in Europe.

Our results based on cytb and COI DNA sequence information showed a large proportion of cow (42.6\%), and a variety of undeclared wild species (41.6\%) with one CITES Appendix I listed species, followed by kangaroo (7\%) and a minor proportion of horse, sheep and pork [2]. A similar approach also allowed for the detection of rat, fox, ferret, and duck meat sold as lamb in China (Shenzhen Academy of Metrology and Quality Inspection, unpublished data). Europe and the USA follow a species-specific DNA and protein based analysis to evaluate the authenticity of meat products' labels. The monitoring exercise conducted by competent authorities in the 27 European countries in April 2013 revealed $4.6 \%$ of horse in meat samples [3].

\section{Comparative analysis of meat authentication systems in Europe, USA and South Africa}

A comparative analysis of the methods used for testing meat authenticity is detailed in Table 1. The EU applied a cut-off level of $1 \%$ horse DNA in the monitoring testing conducted in 2013. Although different methods had been applied in different countries, the possibility of having underestimated the proportion of horse cannot be discarded. The system recommended by the European Union Reference Laboratory for Animal Proteins in Feedstuffs [3,4], spans ND4 mtDNA gene from sites 10378-10464 in the GenBank reference NC_00164. Many horse breeds show polymorphisms in the priming sites (e.g. HQ439485), or both primers and probe sites (e.g. JN398456, JN398401, HQ439446, JN398420, EF597512). This would result in the underestimation of quantity of horse DNA. 
This problem can be extended to other commercial methods. To the best of our knowledge no validation experiments had been shown for different domestic species breeds.

Another inconvenience is the absence of certified standard DNA material or reference biological material in food forensics similar to those standards used in human genetics or human forensics, e.g. the National Institute of Standards and Technology (NIST) Standard Reference Material (SRM), and the HGDP-CEPH Human Genome Diversity Cell Line Panel. To the best of our knowledge, the only reference material available is for fish species (FDA, USA [9]).

Testing kits simplify and accelerate the collection of results, but these methods would not necessarily be appropriate in Africa, Asia or South America, where the consumption of other than domestic species is frequent, or in cases of poor or not implemented monitoring systems, which would allow for unusual deliveries into the mainstream market. Bush meat trade is prominent in Asia and Africa [10], but wild animals are consumed in all continents (kangaroo, bison, etc.).

For instance in South Africa, a CITES Appendix I listed zebra species was detected in the biltong market [2]. Equidae species have a recent evolutionary history. Species ID kits' manuals normally show validations with other domestic species but rarely with phylogenetically close relatives.

Table 1

Meat species authentication methods used in different countries. FSA, Food Standards Agency; CRA-W, Wallon Agricultural Research Center, European Union Reference Laboratory for Animal Protein in Feedingstuffs; FSIS, Food Safety and Inspection Service.

\begin{tabular}{|c|c|c|c|}
\hline Method/kit & Species & Detects & $\begin{array}{l}\text { Used by competent } \\
\text { authorities }\end{array}$ \\
\hline DNA TraceBack ${ }^{10}$ & Pork, beef, horse & Undisclosed DNA fragment & Ireland \\
\hline Neogen F.A.S.T. Immunostick & Beef, horse, pig, poultry, sheep & Undisclosed protein, Elisa & UK \\
\hline PrimerDesign & Horse, beef, sheep, pig & RT-PCR undisclosed mtDNA fragment & UK \\
\hline PCR-CE (FSA method) [4] & Horse & $12 S$ and cytb mtDNA & UK \\
\hline Eurofins & $\begin{array}{l}\text { Beef, pork, horse, sheep, goat, } \\
\text { chicken, turkey }\end{array}$ & $\begin{array}{l}\text { RT-PCR + sequencing undisclosed } \\
\text { mtDNA fragment }\end{array}$ & Ireland \\
\hline Chipron GmbH, Meat Species $1.6^{a}$ & $\begin{array}{l}\text { Beef, buffalo, pig, sheep, goat, } \\
\text { horse, donkey, rabbit, hare, } \\
\text { chicken, turkey, goose, } \\
\text { Mallard duck, Muscovy duck }\end{array}$ & $>150$ bp $16 \mathrm{~S}$ rRNA probe $[5]$ & Bulgaria \\
\hline Microsynth, Tetraplex Real-Time PCR AllMeat & Chicken, pork, beef, turkey & Undisclosed DNA fragment & Germany \\
\hline Microsynth, Tetraplex Real-Time PCR AllHorse & Sheep, pork, beef, horse & GHR (Grow Hormone Receptor gene) [6] & Germany \\
\hline ND4 RT-PCR EU recommended method $[7,8]$ & Horse & ND4 26 bp probe (sites $10378-10464$ ) & France, CRA-W \\
\hline ELISA-TEK $^{\mathrm{TM}}$ ELISA-TEK ${ }^{\mathrm{B}}$ Cooked Meat Species Kit & $\begin{array}{l}\text { Beef, pork, horse, sheep, } \\
\text { chicken, turkey, deer (cooked) }\end{array}$ & $\begin{array}{l}\text { Undisclosed heat-resistant species specific } \\
\text { glycoproteins }\end{array}$ & USA, FDA \\
\hline DTEK $^{\mathrm{TM}}$ Immunostick Kits ${ }^{\mathrm{b}}$ & Raw meat & Undiclosed protein & USA, FSIS \\
\hline $\begin{array}{l}\text { Tepnel Biosystems F.A.S.T. Immunostick } \\
\text { Meat Species Screening Kit }\end{array}$ & $\begin{array}{l}\text { Beef, horse, pig, poultry, } \\
\text { sheep (raw) }\end{array}$ & Undiclosed protein & USA, FDA \\
\hline
\end{tabular}

b Reported cross-reactivity with bison.

The species specific LCD array kit applied in South Africa [1] would leave the presence of kangaroo unnoticed, which was detected by cytb and COI Sanger sequencing [2].

In our experience of identifying game species in meat products cytb was more informative than COI, and allowed for inference of geographic origin on African ungulates [2].

\section{Conclusions and recommendations}

1. Utilization of non species-specific target approach, using cytb and/or COI DNA sequence information in geographic regions where wild animals consumption is frequent or lack an implemented routine testing of food authenticity. 
2. Commercial kits should be validated utilizing close taxonomic relatives to test for cross-reactivity.

3.Commercial kits should be validated using a variety of geographically dispersed breeds.

4. Implementation of certified standard reference material for domestic species accounting for the known range of variation and/or breeds.

\section{Role of funding}

This work was funded by the University of the Western Cape and National Research Foundation.

\section{Conflict of interest}

None.

\section{Acknowledgements}

We thank J. Hill, USDA FSIS USA; R. Hochgger and V. Peteresil, AGES, Austria; M. Rubenova, BSFA Bulgaria; M.-L. Trebes, FMFACP Germany; and G. Berben, CRA-W France for the valuable information provided on their meat testing methods. 


\section{References}

[1] D.-M. Cawthorn, H.A. Steinman, L.C. Hoffman, A high incidence of species substitution and mislabeling detected in meat products sold in South Africa, Food Control 32 (2013) 440-449.

[2] M.E. D'Amato, E. Alechine, K.W. Cloete, et al., Where is the game? Wild meat products authentication in South Africa: a case study Investigative, Genetics 4 (2013) 6.

[3] http://ec.europa.eu/food/food/horsemeat/tests_results_en.htm.

[4] Department of Environment, Food and Rural Affarirs (DEFRA). Method verification of the LOD associated with the Defra/FSA Study protocol for detection of horse DNA in food samples - Final Report (2013) FAO-0134.

[5] A.N. Iwobi, I. Huber, G. Hauner, et al., Biochip Technology for the Detection of Animal Species in Meat Products, Food Analytical Methods 4 (2011) 389- 398.

[6] R. Kö ppel, J. Ruf, J. Rentsch, Multiplex real-time PCR for the detection and quantification of DNA from beef, pork, horse and sheep, European Food Research Technology 232 (2011) 151-155.

[7] EURL, CRA-W. Detection of horse DNA using real-time PCR. EURL-AP recommended protocol. Version 1.o, published 18.02.2013. Available at http://eurl.craw.eu/img/page/sops/Protocol for detection of horse DNA using real-time PCR.pdf. [8] EURL, CRA-W. Addendum to the EURL-AP protocol: Cut-off to check the $1 \%$ level threshold of horse meat in another meat. Available at http://eurl.craw.eu/img/ page/sops/Addendum protocol Horse detection.pdf.

[9]http://www.fda.gov/Food/FoodScienceResearch/DNASeafoodIdentification/default.htm. [10] The Parliamentary Office of Science and Technology. The Bushmeat Trade. PostNote (2005) 236. 